\title{
Characterization of Rat Sodium Channels in Neuroendocrine Cells Using Region-specific Antibodies
}

\author{
Fumiko Kasuga ${ }^{1}$, Shizunobu Igimi', Megumi Nakayama ${ }^{2}$, Toshihiko Iwanaga ${ }^{2}$, James M. Hungerford $^{3}$, \\ Kenji Machit ${ }^{4}$, Susumu Kumagai ${ }^{1}$, Li Jun ${ }^{5}$ and Noboru Yanaihara ${ }^{5}$ \\ 'Department of Biomedical Food Research, National Institute of Infectious Diseases, Toyama 1-23-1, Shinjuku-ku, Tokyo \\ 162-8640, Japan, 'Laboratory of Anatomy, Graduate School of Veterinary Medicine, Hokkaido University, Sapporo 060-0810, \\ Japan, ${ }^{3}$ Seafood Products Research Center, Food and Drug Administration, Bothell, WA 98041, USA, 'Department of Veterinary \\ Public Health, National Institue of Public Health, Minato-ku, Tokyo 108-8638, Japan, ${ }^{5}$ Yanaihara Institute, Inc. Awakura, \\ Fujinomiya 418-0011, Japan
}

(Received 17 November 1999; and accepted 3 December 1999)

\begin{abstract}
Using two anti-peptide antibodies, which recognized a conserved region within subtypes of $\alpha$-subunit of rat sodium channel and a relatively divergent sequence specific to subtype II $\left(\mathrm{R}_{\mathrm{II}}\right)$, rat sodium channels in neuroendocrine cells were examined. Rat adrenal medulla was stained by both antisera; RY 137, which was raised against peptide corresponding to well-conserved region of $\alpha$-subunit between domain 4 segment 5 (D4S5) and D4S6, stained the nucleus of medulla cells, while RY 143, which was raised against $\mathrm{R}_{11}$-specific region between D1S6 and D2S1, stained the cellular membrane. Antisera inhibited the cell burst response of mouse neuroblastoma cell line, Neuro-2a, against the combination treatment with ouabain, veratridine and brevetoxin $\mathrm{PbTx}-1$. These results indicate clearly the region-specific antibodies produced in the present study were useful for detection and characterization of sodium channels in rats.
\end{abstract}

Voltage-dependent sodium channels are transmembrane glycoprotein responsible for sodium ion influx upon the rise in action potential in neurons, skeletal muscles, cardiac and neuroendocrine cells $(1,3,5,9,11)$, and are composed of a large $\alpha$-subunit of $260 \mathrm{kDa}$ as the principal component, which consists of four domains of internal homology. The major actions of the channels reside in the primary structure of this subunit. The purified $\alpha$-subunit protein has been found to be associated with one or two additional proteins such as $\beta 1$ and $\beta 2$ subunits, although the functional significance of these subunits is unclear.

cDNA clones isolated from rat brain encoded

Correspondence to: Dr Fumiko Kasuga at the above address.

Tel: +81-3-5285-1111; Fax: +81-3-5285-1176 three different $\alpha$-subunit mRNAs and those have been sequenced as rat sodium channel subtype I-III $\left(\mathrm{R}_{\mathrm{I}}-\mathrm{R}_{\mathrm{III}}\right)(2,16,18,23)$. The multiple sodium channel subtypes have been found to be expressed not only in organ-specific way (30) but also in tissue-specific $(11,13)$. Specific subcellular localization has also been shown in rats (29).

Anti-peptide antibodies against the fragments of sodium channels were used to identify the localization of sodium channels or of each sodium channel subtype in rat brain and spinal cord $(12,13,29)$. Further, the binding sites for sodium channel-directed neurotoxins $(25,26)$ and functions of specific sites $(4,8,21)$ were investigated. In rat brain, subtype II $\left(\mathrm{R}_{\mathrm{II}}\right)$ was shown to be approximately $80 \%$ of total sodium channels, and was preferentially expressed in the rostral areas of central nervous system $(13,29)$. 
Expression of $\mathrm{R}_{\mathrm{III}}$ seems to be restricted to embryonic and neonatal period (10). Other subtypes of sodium channel have been reported in other organs and tissues (6).

Voltage-dependent sodium channels have also been identified in several neuroendocrine cells which are derived from the neural crest (9). These cells include C-cells, chromaffin cells and pheochromocytoma cells.

We have prepared two different antibodies, one of which, RY 137, was raised in rabbits against synthetic peptide corresponding to a conserved sequence within $\mathrm{R}_{\mathrm{I}}$ and $\mathrm{R}_{\mathrm{II}}$ [Na channel- $\alpha$ 16861705 according to sequence shown by Noda et al. (23): KREVGIDDMFNFETFGNSMI], and the other, RY 143, against peptide corresponding to subtype-specific region for $\mathrm{R}_{\mathrm{II}}$ ( $\mathrm{Na}$ channel- $\alpha$ 467-485: ASAESRDFSGAGGIGVFSE). The characteristics of those antibodies in the immunohistochemical staining of rat adrenal medulla and in biological activities on neuroblastoma cells were described in this report.

\section{MATERIALS AND METHODS}

\section{Synthesis of Peptide Immunogen}

Peptides related to $\alpha$-subunit of rat sodium channels [rat Na channel- $\alpha$ (1686-1705): KREVGIDDMFNFETFGNSMI; rat $\mathrm{Na}$ channel- $\alpha$ (467-485): ASAESRDFSGAGGIGVFSE] were synthesized by solid phase methodology with the Fmoc-strategy using an automated peptide synthesizer (PerSeptive model 9050 plus, USA) in the manner described previously $(22,32)$. Briefly, the peptide chain was elongated on polyethylene glycol-polystyrene resin $(0.80 \mathrm{~g})$. Fmoc-amino acid derivatives (4 equimoles) were activated in the presence of $o$-(7-azabenzotriazol-1-yl)-,1, 1, 3, 3-tetramethyluronium hexafluorophosphate (HATU) (4 equimoles) and diisopropylethanolamine (DIEA) (6 equimoles). The coupling was performed at room temperature for $60 \mathrm{~min}$. After construction of the desired protected peptide resin, the protected peptide resin $(1.21 \mathrm{~g})$ was treated with trifluoroacetic acid $(24 \mathrm{~mL})$ in the presence of $\mathrm{m}$-cresol $(0.6 \mathrm{~mL}), 1,2$ ethanedithiol $(1.8 \mathrm{~mL})$ and thioanisole $(3.6 \mathrm{~mL})$ at $25^{\circ} \mathrm{C}$ for $120 \mathrm{~min}$, followed by treatment of $20 \%$ piperidine/DMF. The resin was removed by filtration, anhydrous ethylether was added to the filtrate to give the crude product. The crude peptide was purified by reverse phase HPLC on a column of YMC-Pack D-ODS-5 $(2.0 \times 25.0 \mathrm{~cm})$ using $0.01 \mathrm{~N} \mathrm{HCl} / \mathrm{CH}_{3} \mathrm{CN}(75 / 25-60 / 40, v / v, 30$ min) as eluent at a flow rate of $7 \mathrm{~mL} / \mathrm{min}$ to yield the desired peptides. Purity of the peptides was assessed by analytical HPLC on a column of YMC-Pack D-ODS-5 $(0.46 \times 25.0 \mathrm{~cm})$ using 0.01 $\mathrm{N} \mathrm{HCl} / \mathrm{CH}_{3} \mathrm{CN}(95 / 5-40 / 60, \mathrm{v} / \mathrm{v}, 30 \mathrm{~min})$ as eluent at a flow rate of $1 \mathrm{~mL} / \mathrm{min}$, and after hydrolysis of synthetic peptides in $6 \mathrm{~N} \mathrm{HCl} / 1 \%$ phenol at $110^{\circ} \mathrm{C}$ for $24 \mathrm{~h}$, the amino acid analysis of the ensuing hydrolysates were performed using a Beckman System 7300 (Beckman, USA).

\section{Anti-synthetic peptide antibody}

Production of antibodies was carried out in the following manner. Synthetic peptide $(1.5 \mathrm{mg})$ without conjugation with macromolecular protein was stirred with a $50 \%(\mathrm{w} / \mathrm{v})$ polyvinylpyrrolidone (MW 25,000-30,000, Merck, Darmstadt, Germany) in $1.5 \mathrm{~mL}$ of saline for $2.5 \mathrm{~h}$ at $25^{\circ} \mathrm{C}$. The mixture was emulsified with $1.5 \mathrm{~mL}$ of Freund's complete adjuvant (Calbiochem Behring, La Jolla, CA, USA) for $10 \mathrm{~min}$ in an ice bath. The emulsion was injected intradermally into two Japanese white female rabbits (about 2.5 $\mathrm{kg}$ ). For primary immunization, each rabbit received a portion of the emulsion containing approximately $1 \mathrm{mg}$ of peptide. Booster injections were given at two-week intervals using half the dose of the immunogen used for the primary immunization. After the fourth injection, the rabbits were bled from the marginal ear vein at ten days after each booster injection. Serum was then subjected to a titer check. Thus, RY 137 which used rat $\mathrm{Na}$ channel- $\alpha$ (1686-1705) KREVGIDDMFNFETFGNSMI as immunogen, and RY 143 which used rat Na channel- $\alpha$ (467485) ASAESRDFSGAGGIGVFSE as immunogen were obtained.

\section{Immunohistochemistry}

Male Wistar rats weighing about $200 \mathrm{~g}$ were used for the immunohistochemical examination. The animals were deeply anesthetized by an intraperitoneal injection of pentobarbital, and perfused with a physiological saline followed with $4 \%$ paraformaldehyde in $0.1 \mathrm{M}$ phosphate buffer ( $\mathrm{pH}$ 7.4). The adrenal gland was removed and immersed in the same fixative for additional $6 \mathrm{~h}$. The fixed tissues were dipped in $30 \%$ sucrose solution for overnight at $4{ }^{\circ} \mathrm{C}$ and quickly frozen in liquid nitrogen. Frozen sections about $20 \mu \mathrm{m}$ 


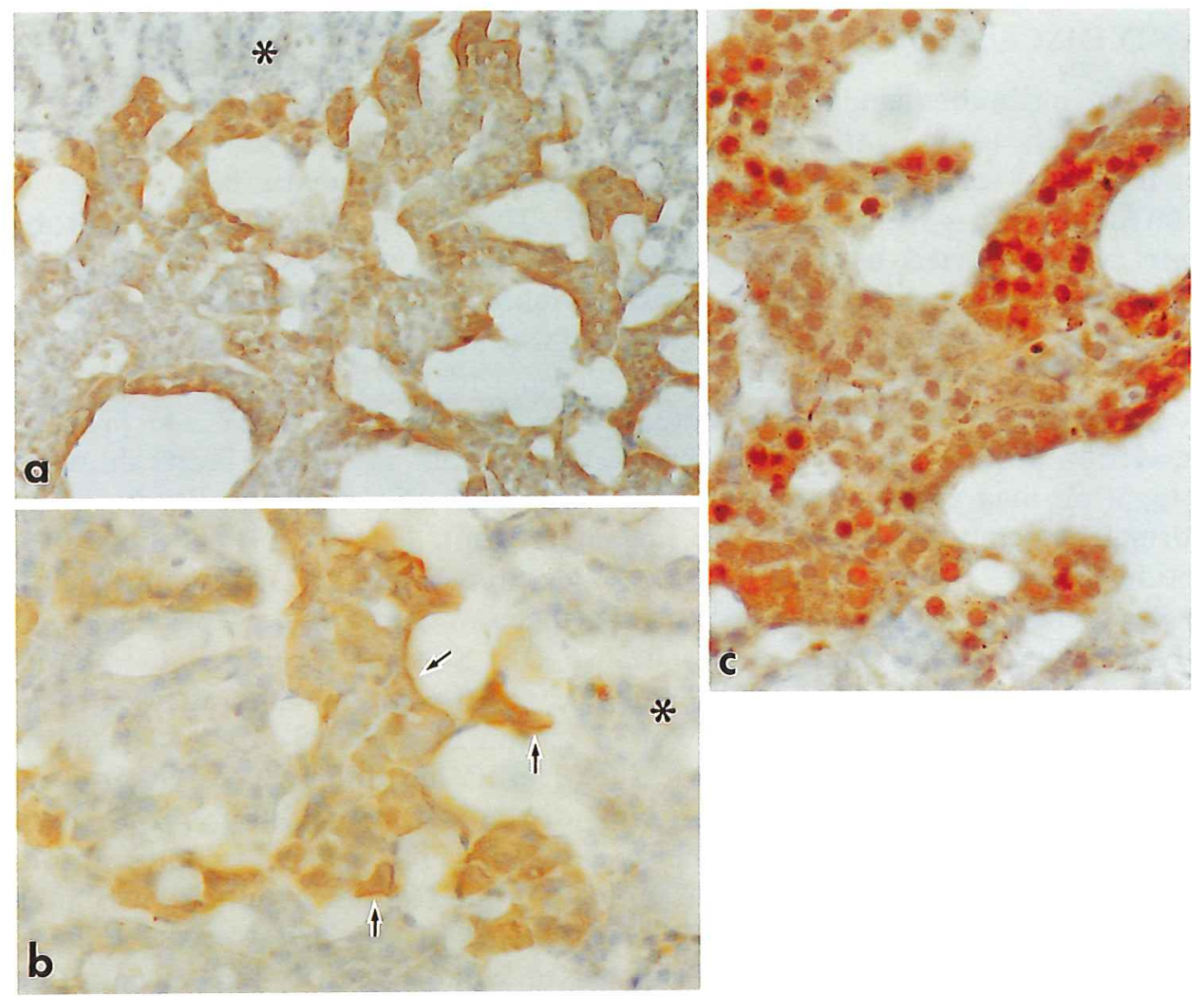

Fig. 1 Immunohistochemistry for Na channel II in the adrenal gland of rats. The immunoreactivity with RY 143 is found selectively in medullary endocrine cells, while the cortex (asterisk) is free from any positive reaction (a). In some chromaffin cells, the intense reactivity with RY 143 apears to be localized at the cell membrane (arrows in b). Antiserum RY 137 also stains cell bodies of chromaffin cells, but more intense reactivity is found in nuclei of the cells (c) $\mathbf{a} \times 200$; $\mathbf{b}$ and $\mathbf{c} \times 400$

thick were prepared in a cryostat (CM 3050; Leica, Nussloch, Germany) and mounted on poly-L-lysine-coated glass slides.

Immunostaining of sodium channel was carried out according to the avidin-biotin complex $(A B C)$ method. The sections were treated with $0.3 \%$ Triton X-100 in $0.1 \mathrm{M}$ phosphate buffered saline $(\mathrm{pH} 7.3)$ for $1 \mathrm{~h}$ and then with $0.3 \% \mathrm{H}_{2} \mathrm{O}_{2}$ in methanol for inhibition of endogenous peroxidase activity. After treatment with a blocking serum for $30 \mathrm{~min}$, the sections were incubated with rabbit serum against rat $\mathrm{Na}$ channel II (RY 137, RY 143) diluted in 1: 3,000 overnight at room temperature. The sections were then incubated with biotinylated goat anti-rabbit immunoglobulins and ABC (Histofine kit; Nichirei, Tokyo, Japan). The antigen-antibody reation was visualized by incubation in $0.05 \mathrm{M}$ Tris- $\mathrm{HCl}$ buffer ( $\mathrm{pH}$ 7.6) containing $0.01 \% \quad 3,3^{\prime}$ diaminobenzidine and $0.002 \% \mathrm{H}_{2} \mathrm{O}_{2}$.

\section{Cell Assay}

Mouse neuroblastoma cell line (Neuro-2a, ATCC CCL-131) was maintained as previously described (20). Cells were plated into 96-well microtiter plates at the concentration of $1 \times 10^{5}$ cells per well in $200 \mu \mathrm{L}$ RPMI 1640 (Sigma, USA) with $5 \%$ FCS. After incubation for 24 hours at $37^{\circ}$ $\mathrm{C}$, the cells received $10 \mu \mathrm{L}$ each of $10 \mathrm{mM}$ ouabain (Sigma, USA), $1 \mathrm{mM}$ veratridine (Sigma, USA), $600 \mathrm{pg} / \mathrm{mL}$ of brevetoxin PbTx-1 (Calbiochem, USA), and then antisera and control serum which had been serially diluted by 4 -fold were added. The cells were further incubated for 5 hours and the cells were assayed with MTT (3-[4, 5-dimethylthiazo1-2-yl]-2, 5-diphenyltetrazolium) (Sigma, USA) as described by Manger et al (20). 


\section{RESULTS AND DISCUSSION.}

In order to obtain antibodies against $\alpha$-subunit of rat sodium channels using synthetic peptides corresponding to partial sequences of the protein, the (1686-1705) and (467-487) sequences of rat sodium channel were selected as immunogens. These sequences are supposed to contain most hydrophilic regions in the $\alpha$-subunit of rat sodium channels. These synthetic peptides were purposely used as immunogens without conjugation to a macro-molecule, since the macromolecule conjugation may result in some chemical and conformational modifications of the immunogen peptide (32).

Two peptides prepared in the present study gave yields of $15.5 \%$ and $16.0 \%$, respectively. The amino acid ratios in acid hydrolysates of these rat sodium channel-related peptides agree well with the expected values, respectively. On analytical reverse phase $\mathrm{HPLC}$ using $\mathrm{CH}_{3} \mathrm{CN}$ (5-60\%), (30 $\min , 1.0 \mathrm{~mL} / \mathrm{min})$ in $0.01 \mathrm{~N} \mathrm{HCl}$, both synthetic peptides, such as rat $\mathrm{Na}$ channel (1686-1705) and (467-485) showed sharp single peaks at 21.0 min and $16.8 \mathrm{~min}$, respectively. Using these two synthetic peptide immunogens, anti-rat $\mathrm{Na}$ channel- $\alpha(1686-1705)$ serum RY 137 and antirat $\mathrm{Na}$ channel- $\alpha$ (467-485) serum RY 143 were raised in rabbits after 5 th immunization and used for immunostaining at a dilution of $1: 3,000$.

Adrenal medulla demonstrated immunoreactivity against both antisera. Figure $1 \mathrm{c}$ shows that the nuclei of chromaffin cells were strongly stained by $R Y$ 137, which recognizes conserved region of $R_{I}$ and $R_{I I}$ between domain 4 segment 5 (D4S5) and D4S6, while the cytoplasm of chromaffin cells was immunoreactive, more intensely in cell membrane, for RY 143, which was raised against peptide corresponding to $\mathrm{R}_{\mathrm{II}^{-}}$ specific sequence between D1S6 and D2S1, as shown in Figure $1 \mathrm{a}, \mathrm{b}$.

The cell burst of mouse neuroblastoma cells, Neuro-2a, which was induced by co-treatment of ouabain, veratridine, and brevetoxin $\mathrm{PbTx}-1$, was inhibited by both antisera. Inhibition was observed with upto $1: 384$ dilution of RY 137 and 1: 98, 304 dilution of RY 143 (Table 1).

$R_{I}$ and $R_{I I}$ have been shown to be major subtypes of $\alpha$-subunit of sodium channel in adult rat brain $(11,13,29)$. Expression of $R_{I}$ and $R_{I I}$ exhibited distinct spatial and temporal patterning, indicating their separated role in the brain (12). Subtype-specific localization of sodium channel was also demonstrated by in situ hybridization of mRNAs $(10,24)$. Region-specific antipeptide antibodies have previously been used to distinguish the distribution of each channel subtype. $\mathrm{R}_{\mathrm{ll}}$, which occupies approximately $80 \%$ of total sodium channels, was preferentially expressed in the rostral areas, while $\mathrm{R}_{\mathrm{I}}$ was expressed homogeneously in the central nervous system $(13,29)$.

In adrenal medulla, whose chromaffin cells are known to be the same embryonic origin with sympathetic ganglionic neurons (19), existence of multiple and species-specific types of sodium channel has been suggested $(7,14,31)$. One of them, human neuroendocrine sodium channel (hNE-Na), has been cloned and its amino acid sequence has been demonstrated (17). This new member of sodium channel family was shown to be expressed in bovine adrenel medulla $(17,31)$.

Table 1 Survival of neuroblastoma cells after the treatment of ouabain, veratridine and brevetoxin PbTx-1 by the addition of anti-rat sodium channel antisera

\begin{tabular}{|c|c|c|c|c|c|c|c|}
\hline \multicolumn{8}{|c|}{$\Delta \mathrm{OD}_{570}$ following MTT assay*1 } \\
\hline & \multicolumn{6}{|c|}{ dilution factor for antisera*2 } & \multirow[b]{2}{*}{393216} \\
\hline & 96 & 384 & 1536 & 6144 & 24576 & 98304 & \\
\hline NRS*3 & 0.1148 & 0.1498 & -0.0922 & -0.0922 & -0.4272 & -0.1382 & -0.4482 \\
\hline RY 137 & $0.3028^{* 4}$ & 0.2578 & 0.1518 & -0.0552 & 0.0868 & 0.0178 & -0.4112 \\
\hline RY 143 & 0.0708 & 0.4228 & 0.4038 & -0.0592 & 0.5068 & 0.3118 & -0.1592 \\
\hline
\end{tabular}

Mouse neuroblastoma cell line, Neuro-2a, was maintained and subjected to the cell assay as described in Materials and Methods. ${ }^{* 1}$; The data shown is the difference from the OD value obtained in the cell group which received only ouabain, veratridine and brevetoxin $\mathrm{PbTx}-1 .{ }^{*}$; Dilution factors indicate the final dilution of serum in the wells. ${ }^{* 3}$; Normal rabbit serum. ${ }^{*}$; ; The values above 0.2000 were judged as positive and were shown in bold letters. 
Outer cellular part of hNE-Na, which in turn corresponds to peptide antigen for antibody RY 137 in $R_{\text {II }}$, has well-conserved sequence of amino acids, whereas the area corresponding to antigen peptide for antibody RY 143 is heterogenous between $\mathrm{R}_{\mathrm{II}}$ and hNE-Na $(17,23)$.

The neuroblastoma cell burst is known to be caused by the enhanced $\mathrm{Na}^{+}$influx and then water inflow with the stimulation of veratridine and brevetoxin in the combination of sodium pump blockade with ouabain (20). Inhibition of the burst suggests that the antisera blocked excess influx of sodium ion into the cells in a pharmacological or a physical manner. Since the antibody RY 143 recognizes the inner cellular part of $\alpha$-subunit of $\mathrm{R}_{\mathrm{II}}$, the cell burst inhibition may be caused first by the opening of sodium channel with the toxins to allow transfer of the antibodies into the cells with water, followed by the antibody binding to the channel to restrain further influx of sodium ion and water and then swelling of the cells.

The present study demonstrated that the regionspecific antibodies described above were useful for detection and characterization of sodium channels in rat neuroendocrine cells.

\section{REFERENCES}

1. Agnew, W. S. (1984) Voltage-regulated sodium channel molecules. Annu. Rev. Physiol, 46, 517-530.

2. Auld, F. J., Goldin, A. L., Krafte, D. S., Marshall, J., Dunn, J. M., Catterall, W. A., Lester, H. A., Davidson, N. and Dunn, R. J. (1988) A rat brain $\mathrm{Na}^{+}$channel alpha subunit with novel gating properties. Neuron 1, 449-461.

3. Barchi, R. L., Tanaka, J. D. and Furman, R. E. (1984) Molecular characteristics and functional reconstitution of muscle voltage-sensitive sodium channels. J. Cell Biochem. 26, 135-146.

4. Beck, W., Jung, G., Bessler, W. G., Benz, K. and Kohlhardt, M. (1994) Conformational mapping of the cytosolic linker between domains III and IV of the cardiac $\mathrm{Na}^{+}$ channel protein and binding studies with a site-directed channel modifying antibody. Biochim. Biophys. Acta 1206, 263-271.

5. Catteral, W. A. (1984) The molecular basis of neuronal excitability. Science 223, 653-661.

6. Catteral, W. A. (1986) Molecular properties of voltagesensitive sodium channels. Anmu. Rev. Biochem. 55, 953985.

7. Conceiçao, I. M., Lebrun, I., Cano-Abad, M., Gandía, L, Hernández-Guijo, J. M., López, M. G., Villarroya, M., Jurkiewicz, A. and García, A. G. (1998) Synergism between toxin- $\gamma$ from Brazilian scorpion Tityus serrulatus and veratridine in chromaffin cells. Am. J. Physiol. 274, C1745-C1754.

8. Deerinck, T. J., Levinson, S. R., Bennett, G. V. and Ellisman, M. H. (1997) Clustering of voltage-sensitive sodium channels on axons is independent of direct Schwann cell contact in the dystrophic mouse. I. Neurosci. 17, 5080-5088.

9. Fenwick, E. M., Marty, A. and Neher, E. (1982) Sodium and calcium channels in bovine chromaffin cells. $J$. Physiol. 331, 599-635.

10. Furuyama, T., Morita, Y., Inagaki, S. and Takagi, H. (1993) Distribution of I, II and III subtypes of voltagesensitive $\mathrm{Na}^{+}$channel mRNA in the rat brain. Mol. Brain Res. 17, 169-173.

11. Goldin, A. L. (1999) Diversity of mammalian voltagegated sodium channels. In: Molecular and Functional Diversity of Ion Channels and Receptors. Rudy, B. and Seeburg, P. (eds.), Ann. N.Y. Acad. Science 868, The New York Academy of Sciences, New York, pp.38-50.

12. Gong, B., Rhodes, K. J., Bekele-Arcuri, Z. and Trimmer, J. S. (1999) Type I and type II $\mathrm{Na}(+)$ channel alpha-subunit polypeptides exhibit distinct spatial and temporal patterning, and association with auxiliary subunits in rat brain. $J$. Comp. Neurol. 412, 342-352.

13. Gordon, D., Merrick, D., Auld, V., Dunn, R., Goldin, A. L., Davidson, N. and Catterall, W. A. (1987) Tissuespecific expression of the $R_{1}$ and $R_{I I}$ sodium channel subtypes. Proc. Natl. Acad. Sci. USA. 84, 8682-8686.

14. Hollins, B. and Ikeda, S. R. (1996) Inward currents underlying action potentials in rat adrenal chromaffin cells. $J$. Neurophysiol. 76, 1195-1211.

15. Islas-Suárez, L., Gómez-Chavarín, M., Drucker-Colín, R. and Hernández-Cruz, A. (1994) Properties of the sodium current in rat chromaffin cells exposed to nerve growth factor in Vitro. J. Neurophysiol. 72, 1938-1948.

16. Kayano, T., Noda, M., Flockerzi, V., Takahashi, H. and Numa, S. (1988) Primary structure of rat brain sodium channel III deduced from the cDNA sequence. FEBS Lett. 228, 187-194.

17. Klugbauer, N., Lacinova, L., Flockerzi, V. and Hofmann, F. (1995) Structure and functional expression of a new member of the tetrodotoxin-sensitive voltage-activated sodium channel family from human neuroendocrine cells. The EMBO J. 14, 1084-1090.

18. Lu, C. M. and Brown, G. B. (1998) Isolation of a humanbrain sodium-channel gene encoding two isoforms of the subtype III $\alpha$-subunit. J. Mol. Neurosci. 10, 67-70.

19. Malmejac, J. (1964) Activity of the adrenal medulla and its regulation. Physiol. Rev. 44, 186-218.

20. Manger, R. L, Leja, L. S., Lee, S. Y., Hungerford, J. M., Hokama, Y., Dickey, R. W., Granade, H. R., Lewis, R., Yasumoto, T. and Wekell, M. M. (1995) Detection of sodium channel toxins: derected cytotoxicity assays purified chguatoxins, brevetoxins, saxitoxins, and seafood extracts. J. AOAC. Int. 78, 521-527.

21. Nakayama, H., Shikano, H. and Kanaoka, Y. (1992) A site-directed antibody that inhibits phosphorylation of the rat-brain sodium channel by cyclic-AMP-dependent protein kinase. Biochim. Biophys. Acta. 1175, 67-72.

22. Nishikawa, Y., Nagasawa, S., Yanaihara, N., Iguchi, K., Mochizuki, T., Hoshino, M., Iwanaga, T. and Yanaihara, C. (1998) Immunoreactive chromogranin A in rat plasma and urine measured by region-specific radioimmunoassay. Bioned. Res. 19, 237-244.

23. Noda, M., Ikeda, T., Kayano, T., Suzuki, H., Takeshima, H., Kurasaki, M., Takahashi, H. and Numa, S. (1986) Existence of distinct sodium channel messenger RNAs in rat brain. Nature 320, 188-192. 
24. Oh, Y., Sashihara, S. and Waxman, S. G. (1994). In situ hybridization localization of the $\mathrm{Na}^{+}$channel $\beta 1$ subunit mRNA in rat CNS neurons. Neurosci. Lett. 176, 119-122.

25. Trainer, V. L., Baden, D. G. and Catterall, W. A. (1994) Identification of peptide components of the brevetoxin receptor site of rat brain sodium channels. J. Biol. Chem. 269, 19904-19909.

26. Trainer, V. L., Brown, G. B. and Catterall, W. A. (1996) Site of covalent labeling by a photoreactive batrachotoxin derivative near transmembrane segment IS6 of the sodium channel alpha subunit. J. Biol. Chem. 271, 11261-11267.

27. Wada, A., Uezono, Y., Arita, M., Yanagawa, Y., Satake, M. and Izumi, F. (1990) Conotoxin GIIIA: selective inhibition of ${ }^{22} \mathrm{Na}$ influx via voltage-dependent $\mathrm{Na}$ channels in adrenal medullary cells. Naunyn-Schmiedeberg's Arch Pharmacol. 342, 323-327.

28. Wada, A., Uezono, Y., Arita, M., Yuhi, T, Kobayashi, H., Yanagihara, N. and Izumi, F. (1992) Cooperative modulation of voltage-dependent sodium channels by brevetoxin and classical neurotoxins in cultured bovine adrenal medullary cells. J. Pharmacol. Exp. Therapeutics 263, 1347-1351.

29. Westenbroek, R. E., Merrick, D. K. and Catterall W. A.
(1989) Differential subcellular localization of the $R_{I}$ and $\mathrm{R}_{\mathrm{II}} \mathrm{Na}^{+}$channel subtypes in central neurons. Neuron 3, 695-704.

30. Wollner, D. A. and Catterall, W. A. (1985) Antigenic differences among the voltage-sensitive sodium channels in the peripheral and central nervous systems and skeletal muscle. Brain Res. 331, 145-149.

31. Yamamoto, R., Yanagita, T., Kobayashi, H., Yuhi, T., Yokoo, H. and Wada, A. (1996) Up-regulation of functional voltage-dependent sodium channels by insulin in cultured bovine adrenal chromaffin cells. J. Neurochem. 67, 1401-1408

32. Yanaihara, H., Hata, M., Nishikawa, Y., Hoshino, M., Yanaihara N. and Murai, M. (1999) Application of region-specific immunoassay for human chromogranin $\mathrm{A}$ : Substantial clue for detection and measurement of chromogranin A in human plasma. Regul. Peptides 80, 83-90.

33. Yuhi, T., Wada, A., Yamamoto, R., Urabe, M., Niina, H., Izumi, F. and Yanagita, T. (1994) Characterization of $\left[{ }^{3} \mathrm{H}\right]$ brevetoxin binding to voltage-dependent sodium channels in adrenal medullary cells. NaunynSchmiedeberg's Arch Pharmacol. 350, 209-212. 